\title{
Histomorphological studies of broiler chicken fed diets supplemented with either raw or enzyme treated dandelion leaves and fenugreek seeds
}

\author{
Saim Qureshi ${ }^{1}$, Mohammed Tufail Banday ${ }^{1}$, Irfan Shakeel ${ }^{1}$, Sheikh Adil ${ }^{1}$, Masood Saleem Mir ${ }^{2}$, Yasir Afzal Beigh ${ }^{3}$ \\ and Umar Amin
}

\begin{abstract}
1. Division of Livestock Production and Management, Faculty of Veterinary Sciences and Animal Husbandry, Sher-e-Kashmir University of Agricultural Sciences \& Technology of Kashmir, Shuhama - 190 006, Srinagar, Jammu and Kashmir, India; 2. Division of Veterinary Pathology, Faculty of Veterinary Sciences and Animal Husbandry, Sher-e-Kashmir University of Agricultural Sciences \& Technology of Kashmir, Shuhama - 190 006, Srinagar, Jammu and Kashmir, India;

3. Division of Animal Nutrition, Faculty of Veterinary Sciences and Animal Husbandry, Sher-e-Kashmir University of

Agricultural Sciences \& Technology of Kashmir, Shuhama -190 006, Srinagar, Jammu and Kashmir, India.
\end{abstract}

Corresponding author: Sheikh Adil, email: aadilsheikh5@gmail.com,

SQ: s.qureshi619@gmail.com, MTB: mtbanday5@gmail.com, IS: erfaanshakeel3@gmail.com,

MSM: masoodmir11@gmail.com, YAB: vetyasir10@gmail.com, UA: umaramin146@gmail.com

Received: 08-10-2015, Revised: 20-01-2016, Accepted: 27-01-2016, Published online: 12-03-2016

doi: 10.14202/vetworld.2016.269-275 How to cite this article: Qureshi S, Banday MT, Shakeel I, Adil S, Mir MS, Beigh YA, Amin U (2016) Histomorphological studies of broiler chicken fed diets supplemented with either raw or enzyme treated dandelion leaves and fenugreek seeds, Veterinary World, 9(3): 269-275.

\begin{abstract}
Aim: Herbal plants and their derived products are extensively used particularly in many Asian, African, and other countries of the world as they are considered as ideal feed additives because of their non-residual effect and ability to influence the ecosystem of gastrointestinal microbiota in a positive way. Further, the enzymatic treatment of these herbs helps in their efficient utilization by the host. Dandelion leaves and fenugreek seeds have been reported to have positive effect in terms of improving the performance of broiler chicken, but not much literature is available regarding their effect on gut histomorphology; therefore, the present study was conducted to explore the effect of these herbs either alone or in combination with or without enzyme treatment on histomorphology of liver and small intestine of broiler chicken.
\end{abstract}

Materials and Methods: To achieve the envisaged objective, 273-day-old commercial broiler chicks were procured from a reputed source and reared together until 7 days of age. On the $7^{\text {th }}$ day, the chicks were individually weighed, distributed randomly into 7 groups of 3 replicates with 13 chicks each. Birds in the control group were fed diets without additives $\left(\mathrm{T}_{1}\right)$. The other six treatment groups were fed the basal diet supplemented with $0.5 \%$ dandelion leaves $\left(\mathrm{T}_{2}\right), 1 \%$ fenugreek seeds $\left(\mathrm{T}_{3}\right)$, combination of $0.5 \%$ dandelion leaves and $1 \%$ fenugreek seeds $\left(\mathrm{T}_{4}\right)$, enzyme treated dandelion leaves $0.5 \%\left(\mathrm{~T}_{5}\right)$, enzyme treated fenugreek seeds $1 \%\left(\mathrm{~T}_{6}\right)$, and combination of enzyme treated dandelion leaves $(0.5 \%)$ and $(1 \%)$ fenugreek seeds $\left(\mathrm{T}_{7}\right)$. The histomorphological study of liver and small intestines was conducted among different treatment groups.

Results: The results revealed the hepato-protective nature of both dandelion leaves and fenugreek seeds either alone or in combination with or without enzyme treatment when compared with the control group. Moreover, the histomorphological findings of jejunum revealed the beneficial effect of dandelion leaves, fenugreek seeds and enzymes on the intestinal mucosa in terms of cellular infiltration, architecture of villi, villus height/crypt depth ratio, thereby improving the intestinal health.

Conclusion: The dandelion leaves and fenugreek seeds have hepato-protective nature and beneficial effect on the intestinal morphology particularly when included along with enzymes in the diet of broiler chicken.

Keywords: broiler chicken, dandelion, fenugreek, histomorphology.

\section{Introduction}

Phytogenics are a group of natural growth promoters or non-antibiotic growth promoters derived from herbs, spices, or other plants. Compared with synthetic antibiotics or inorganic chemicals, these plant-derived products have proven to be safe, less toxic, residue free and are thought to be ideal feed additives in food animal production. Phytogenic feed additives have gained increasing interest, especially

Copyright: Qureshi, et al. Open Access. This article is distributed under the terms of the Creative Commons Attribution 4.0 International License (http://creativecommons.org/licenses/ by/4.0/), which permits unrestricted use, distribution, and reproduction in any medium, provided you give appropriate credit to the original author(s) and the source, provide a link to the Creative Commons license, and indicate if changes were made. The Creative Commons Public Domain Dedication waiver (http:// creativecommons.org/publicdomain/zero/1.0/) applies to the data made available in this article, unless otherwise stated. for their application in poultry diets [1]. They beneficially affect the ecosystem of gastrointestinal microbiota through controlling potential pathogens and improving digestive capacity in the small intestine and stabilizing the microbial eubiosis in the gut [2]. The herbal plant extracts help in the alteration of intestinal microbiota, increase of enzyme secretion, improvement of the immune response, and histomorphological maintenance of the gastrointestinal tract [3].

Kashmir, often referred to as paradise on earth, is located at the northwestern tip of Himalayan biodiversity hotspot [4]. The region supports a rich and spectacular plant biodiversity of great scientific curiosity and promising economic benefits. Among the herbal flora available in the region, two herbal plants, i.e., dandelion leaves (Taraxacum officinale) and seeds of fenugreek (Trigonella foenum-graecum) were utilized for 
the study of the diets of the broiler chicken. Dandelion is a well-known medicinal plant that grows in nature in Asia, Europe, and North America [5]. The roots of the herb are primarily considered for supporting digestion and liver function, while as its leaves are used as diuretic and digestive stimulant [6]. Fenugreek is grown mainly in India, Pakistan, and China. Its seeds have many therapeutical effects such as hypoglycemic, anti-helminthic, anti-inflammatory, and anti-microbial properties [7]. It also contains lecithin and choline that help to dissolve cholesterol and fatty substances. It also contains neurin, biotin, and trimethylamine which tends to stimulate the appetite by their action on the nervous system [8]. The dietary supplementation of dandelion leaves and fenugreek seeds have been reported to increase the performance of broiler chicken [9-11]. Enzyme supplementation in poultry diets has been reported to improve the performance [12] by degrading non-starchy polysaccharides, improving the digestion and absorption of nutrients [13], and improving their intestinal morphology [14].

Since, dandelion leaves and fenugreek seeds were reported to have positive effect in terms of improving the performance of broiler chicken, but not much literature is available regarding their effect on gut histomorphology; therefore, the present study was conducted to explore the effect of these herbs either alone or in combination with or without enzyme treatment on histomorphology of liver and small intestine of broiler chicken.

\section{Materials and Methods \\ Ethical approval}

The study was conducted after approval of research committee and institutional ethical committee.

\section{Methodology}

273-day-old commercial broiler chicks procured from a reputed source were utilized for the study which lasted 42 days. Chicks were reared in battery cages until 7 days of age. During this period, all the birds were provided with a pre-starter mash $(23 \%$ crude protein and $2800 \mathrm{Kcal} / \mathrm{kg}$ metabolizable energy). Birds had free access to feed and water throughout and were maintained on a constant $24 \mathrm{~h}$ light schedule. On the $8^{\text {th }}$ day, the chicks were individually weighed, distributed into seven treatment groups of three replicates with 13 chicks in each in a completely randomized design so that the treatment means differ as little as possible. Birds in the control group were fed diets without additives $\left(\mathrm{T}_{1}\right)$. The other six treatment groups were fed the basal diet supplemented with $0.5 \%$ dandelion leaves $\left(\mathrm{T}_{2}\right), 1 \%$ fenugreek seeds $\left(\mathrm{T}_{3}\right)$, combination of $0.5 \%$ dandelion leaves and $1 \%$ fenugreek seeds $\left(\mathrm{T}_{4}\right)$, enzyme treated dandelion leaves $0.5 \%\left(\mathrm{~T}_{5}\right)$, enzyme treated fenugreek seeds $1 \%\left(\mathrm{~T}_{6}\right)$, and combination of enzyme treated dandelion leaves $(0.5 \%)$ and $(1 \%)$ fenugreek seeds $\left(\mathrm{T}_{7}\right)$. The diets were formulated to meet the recommendations of the Bureau of
Indian standards [15]. Dandelion leaves (T. officinale) and fenugreek seeds (T. foenum-graecum) were procured, dried and in powder form mixed thoroughly in aforesaid quantities to a small amount of feed $(1 \mathrm{~kg})$ in a premixer. The resultant mixture was then mixed with the rest of the feed in a mechanical blender until a thorough and consistent mixture was obtained. All chicks were vaccinated against Ranikhet disease on the 5th day with F1 strain vaccine and infectious bronchitis virus-95 vaccine against infectious bursal disease on the 16th day. Chicks were checked twice daily for mortality if any. Birds were kept under the same managerial, hygienic, and environmental conditions.

\section{Parameters recorded}

For the histopathological analysis, the tissue samples from liver (main organ of biotransformation) jejunum (main site for absorption) were collected from the slaughtered birds (6 birds per treatment) at the end of experimental period (42 days) and fixed in $10 \%$ buffered formalin saline. Tissues were dehydrated by immersing through a series of alcohols of increasing concentrations (from $70 \%$ to absolute), infiltrated with xylene, and embedded in paraffin. The casting of blocks was carried out in L-molds (two L-shaped pieces) which facilitated the manipulation of size as per the requirement. The rotary type microtome was used for cutting the paraffin sections. The blocks were properly trimmed, and the sections of $5 \mathrm{~mm}$ thickness were cut. Continuous ribbons (6-7 inches long) of the material were cut and laid on the surface of constant temperature water bath (around $55^{\circ} \mathrm{C}$ ). The sections were separated with a heated scalpel after they spread completely. The cut sections were mounted on the clean glass slides using Mayer's egg albumin as the section adhesive. The mounted slides were dried in paraffin oven at $60^{\circ} \mathrm{C}$ for $1 \mathrm{~h}$. The tissue sections were stained by the Harris hematoxylin and eosin staining method. The paraffin sections were deparaffinized with the xylene before hydration through graded alcohol to distilled water. This was followed by the dehydration in ascending grades of alcohol. The clearing was performed in the xylene, and a drop of distrene plasticizer xylene mountant was placed on a coverslip and the section on the slide pressed on it. The slide was inverted, and the cover slip was pressed with a rod to remove the air bubbles if any trapped. The values were measured with an oculometer at a magnification of $\times 10$ under a light microscope fitted with the stage micrometer.

\section{Results}

\section{Liver}

The histomorphological examination of liver from the control group $\left(\mathrm{T}_{1}\right)$ showed a mild degree of hepatocellular degeneration with occasional distortion of hepatic cords associated with Kupffer cell hyperplasia. Frequently marked mononuclear cell infiltration was observed in perivascular area and occasional heterophil forming aggregates of various sizes were noted in the liver parenchyma (Figures-1 and 2). Compared 
to control, $\mathrm{T}_{2}$ group had occasional and only mild perivascular mononuclear cell infiltration (Figure-3). The $\mathrm{T}_{3}$ group showed less hepatocellular degeneration, Kupffer cell hyperplasia and perivascular mononuclear cell infiltration and occasional heterophil aggravate in the parenchyma, but the changes were less severe than the control group (Figure-4). Liver from $\mathrm{T}_{4}$ showed hepatocyte regeneration (Figure-5), $\mathrm{T}_{5}$ (Figure-6), and $\mathrm{T}_{6}$ (Figure-7) had less hepatocellular degenerative changes and diffuse inflammatory cell infiltration. The Group $\mathrm{T}_{7}$ showed normal architecture and beneficial effect on liver (Figure-8).

\section{Small intestine}

The histological examination of jejunum showed an improvement in the jejunal villus height $(\mathrm{p}<0.05)$ and villus height/crypt depth ratio in all the groups fed dandelion leaves and fenugreek seeds with or without enzyme treatment compared to control (Table-1). The control group $\left(\mathrm{T}_{1}\right)$ showed mucous degeneration of glandular epithelium at certain places, diffuse infiltration of inflammatory cells, predominantly heterophils in mucosa in addition to clubbing of villi (Figures-9 and 10). The $T_{2}$ group had normal villus architecture with mild cellular infiltration in mucosa and sub-mucosa; occasional clubbing of villi with less severe infiltration of inflammatory cells than control group was noted (Figure-11). The Group T3 revealed an increase in thickness and height of villi as compared to control

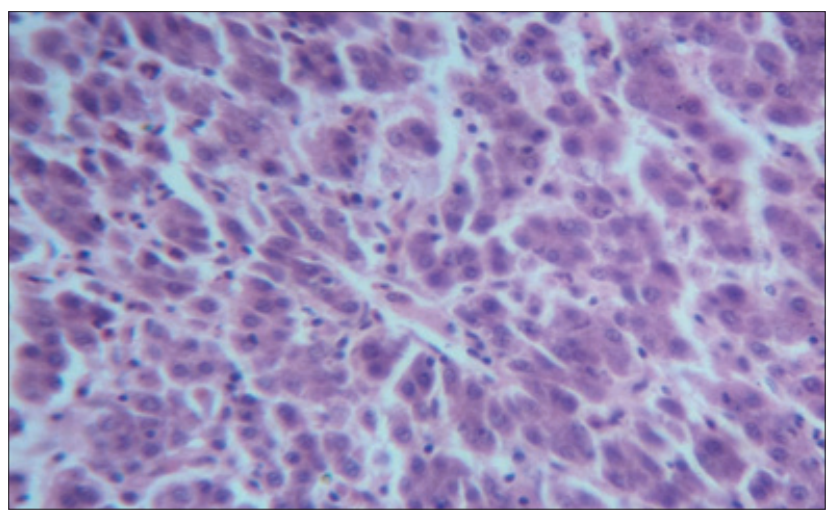

Figure-1: Liver from control group $\left(T_{1}\right)$ showing mild degree of inflammation with occasional Kupffer cell hyperplasia and distortion of hepatic cords ( $\mathrm{H}$ and $\mathrm{E}, \times 4)$.

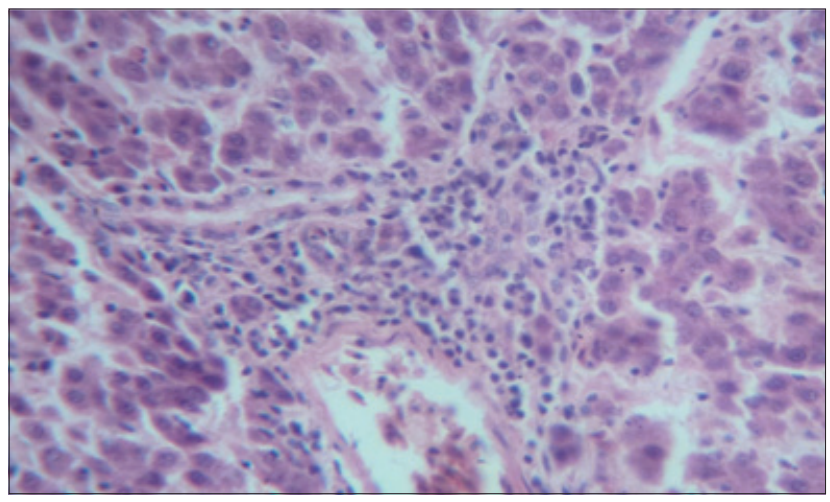

Figure-2: Liver from control group $\left(T_{1}\right)$ showing heterophil aggregates $(\mathrm{H}$ and $\mathrm{E}, \times 4)$.

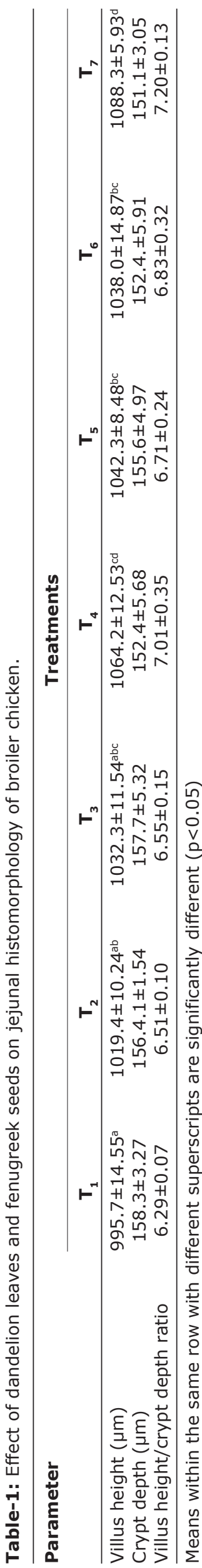

Veterinary World, EISSN: 2231-0916 


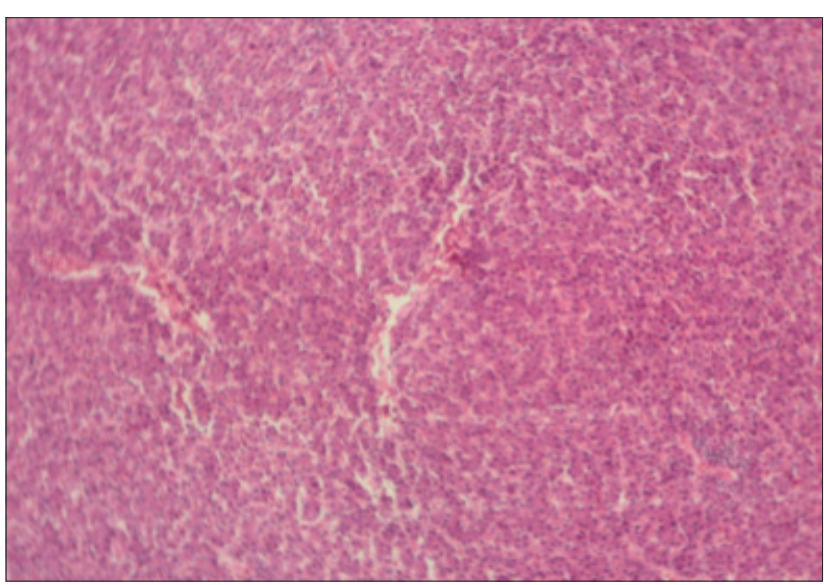

Figure-3: Liver from $T_{2}$ showing occasional and only mild perivascular mononuclear cell infiltration $(\mathrm{H}$ and $\mathrm{E}, \times 4)$.

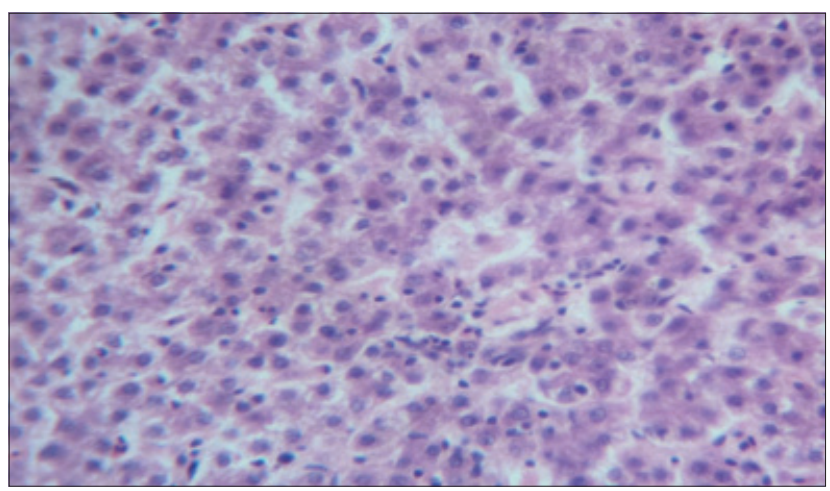

Figure-4: Liver from $\mathrm{T}_{3}$ showing less Kupffer cell hyperplasia and perivascular mononuclear cell infiltration $(\mathrm{H}$ and $\mathrm{E}, \times 4)$.

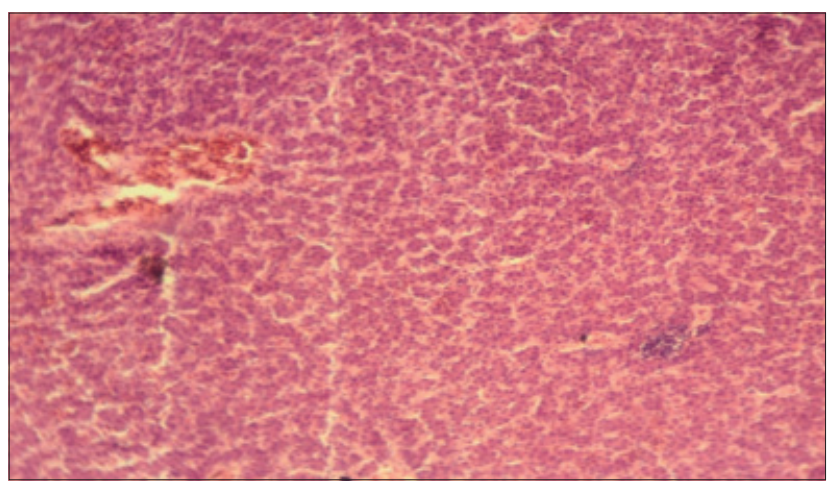

Figure-5: Liver from $T_{4}$ showing hepatocyte regeneration and less heterophil infiltration ( $\mathrm{H}$ and $\mathrm{E}, \times 4)$.

and mild cellular infiltration with occasional distortion of villi was also observed (Figure-12). Compared to control, $\mathrm{T}_{4}$ showed normal villus architecture and increase in height of villi (Figure-13). Jejunum from $\mathrm{T}_{5}, \mathrm{~T}_{6}$, and $\mathrm{T}_{7}$ had normal villus architecture, increase in height of villus and occasional areas of cellular infiltration than $\mathrm{T}_{1}$ (Figures-14-16).

\section{Discussion}

\section{Liver}

The histological examination of liver in different treatment groups revealed the hepato-protective role of both dandelion leaves and fenugreek seeds. There

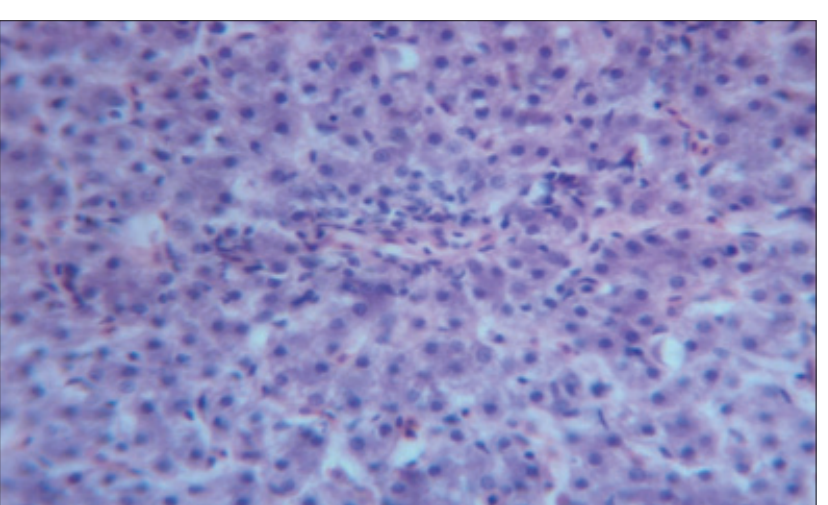

Figure-6: Liver from $T_{5}$ showing less hepatocellular degenerative changes and diffuse inflammatory cell infiltration ( $\mathrm{H}$ and $\mathrm{E}, \times 4)$.

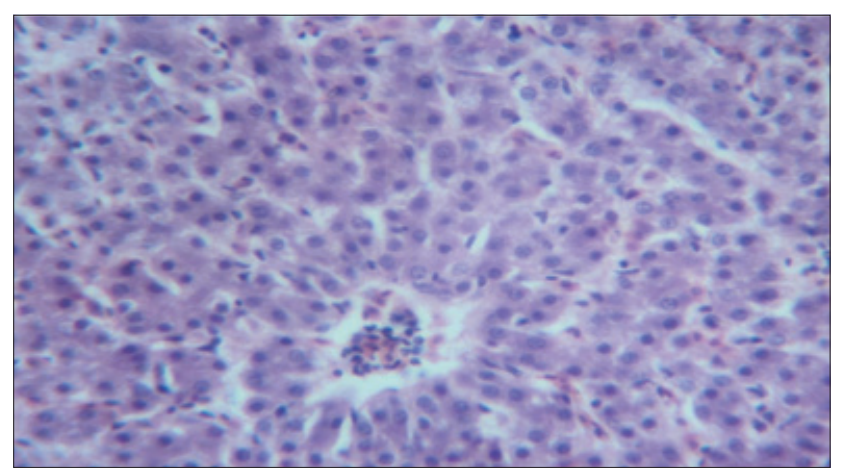

Figure-7: Liver from $\mathrm{T}_{6}$ showing less hepatocellular degenerative changes and diffuse inflammatory cell infiltration ( $H$ and $E, \times 4)$.

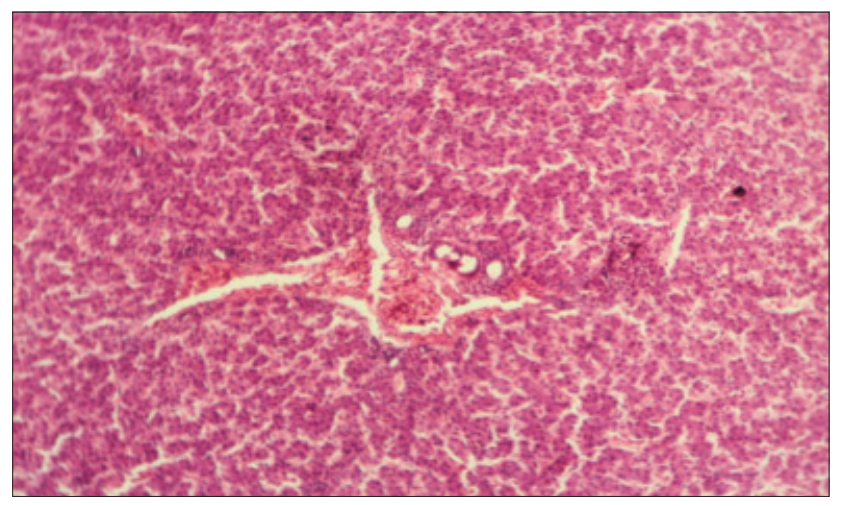

Figure-8: Liver from $\mathrm{T}_{7}$ showing normal architecture and beneficial effect on liver $(H$ and $E, \times 4)$.

was increased hepato-regeneration in the treatment groups where dandelion leaves and fenugreek seeds were supplemented in the diet when compared to the control group. Further, there was a decrease in Kupffer cell hyperplasia and perivascular mononuclear cell infiltration. Best results were observed where both dandelion leaves and fenugreek seeds were used along with enzymes $\left(\mathrm{T}_{7}\right)$. The results of the present study coincide with the results of Park et al. [16], Tabassum et al. [17], Al-Malki et al. [18], and Gulfraz et al. [19] who reported the hepato-protective role of dandelion leaves. Likewise, fenugreek seeds have also been reported to have a hepato-protective impact $[20,21]$. The hepato-protective role of dandelion leaves might 


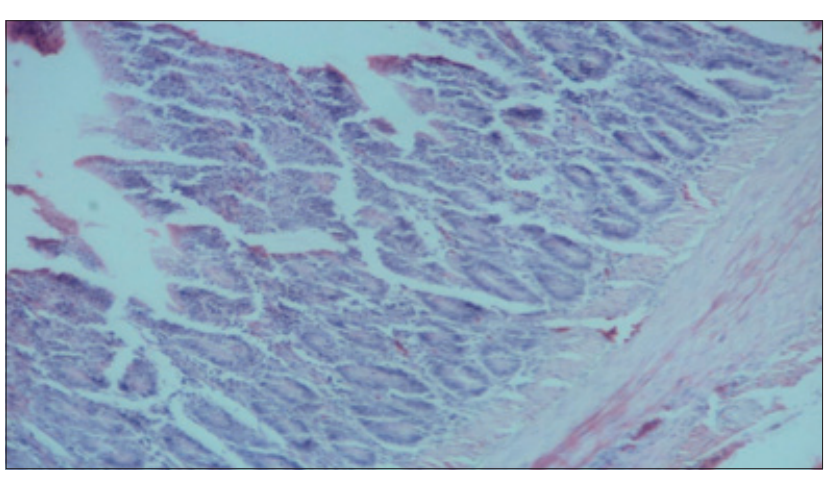

Figure-9: Jejunum from control group $\left(T_{1}\right)$ showing mucous degeneration of glandular epithelium at certain places $(\mathrm{H}$ and $\mathrm{E}, \times 2.5)$.

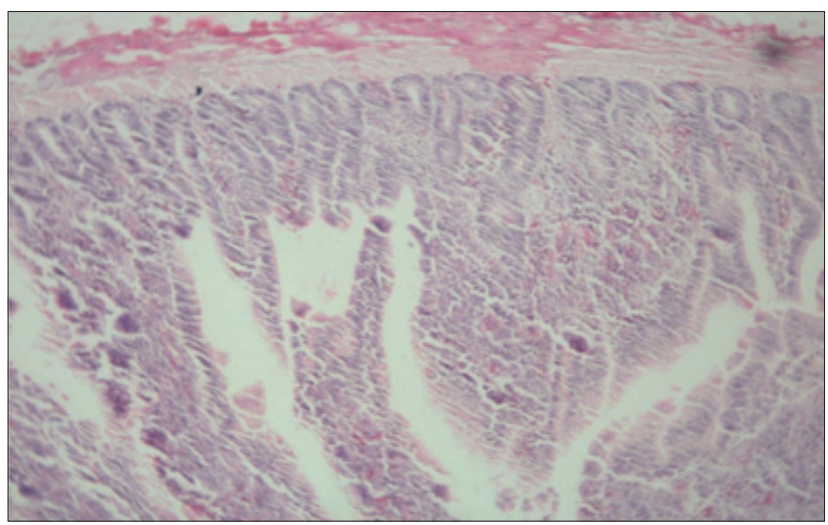

Figure-10: Jejunum from control group $\left(T_{1}\right)$ showing diffuse infiltration of inflammatory cells, predominantly heterophils and clubbing of villi $(H$ and $E, \times 2.5)$.

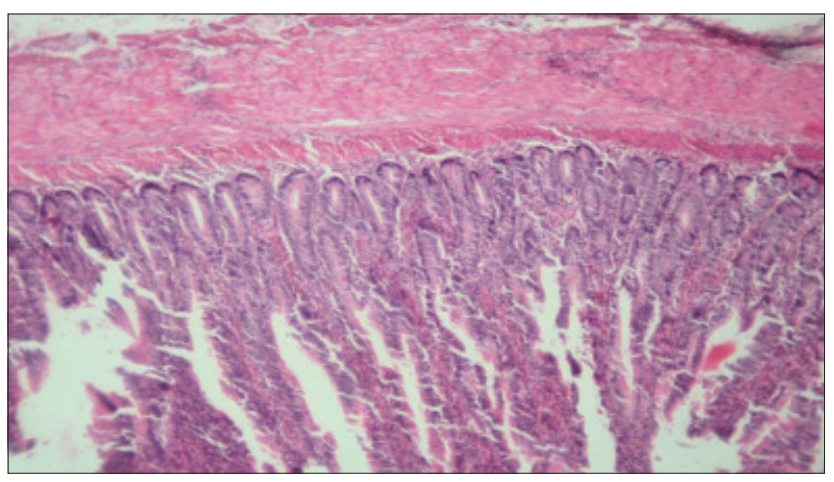

Figure-11: Jejunum from $T_{2}$ showing normal villus architecture with mild cellular infiltration in mucosa and sub-mucosa ( $\mathrm{H}$ and $\mathrm{E}, \times 2.5)$.

be attributed to the bioactive components present in it such as Vitamins (A, C, thiamine, and riboflavin), sesquiterpene lactones, triterpenes, carotenoids (lutein), fatty acids (myristic), and flavonoids (apigenin and luteolin) present in it $[17,22,23]$. Bitter compounds present in dandelion leaves have been reported to increase the production of bile from gall bladder thereby improving the liver function [24]. Further, the hepato-protective role of fenugreek seeds might be attributed to the bioactive ingredients present in it, which enhance hepatic function and due to its antioxidant activity as reported by Bukhari et al., [25] who

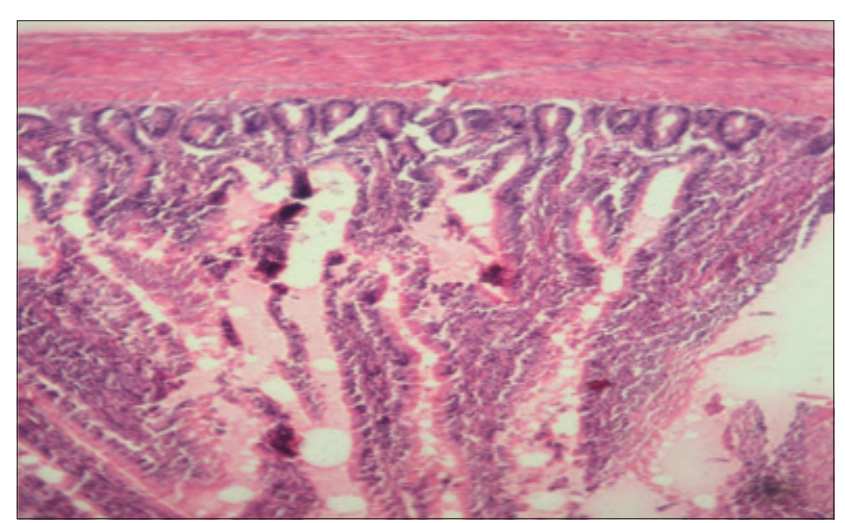

Figure-12: Jejunum from $\mathrm{T}_{3}$ showing normal villus architecture with increase in thickness of villus, less and occasional areas of distortion ( $\mathrm{H}$ and $\mathrm{E}, \times 2.5)$.

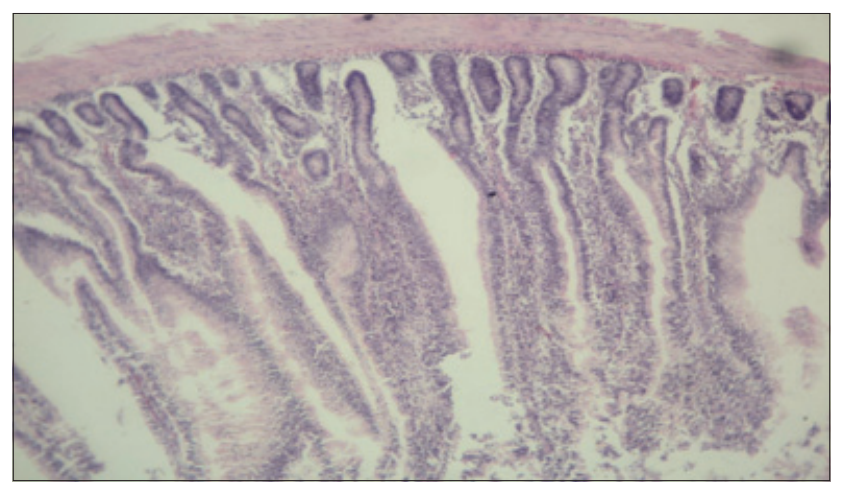

Figure-13: Jejunum from $T_{4}$ showing normal villus architecture, increase in height of villi ( $H$ and $E, \times 2.5)$.

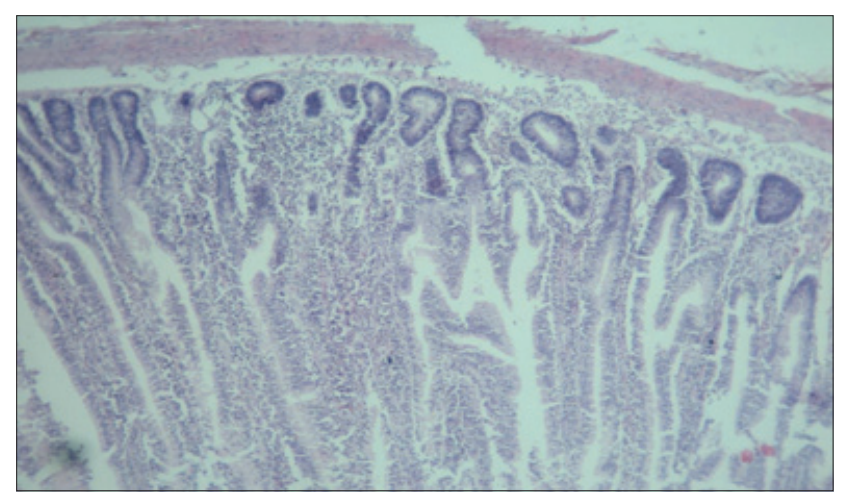

Figure-14: Jejunum from $T_{5}$ showing normal villus architecture, increase in height of villus, occasional areas of cellular infiltration ( $H$ and $E, \times 2.5)$.

reported the antioxidant capacity of the fenugreek extracts.

\section{Small intestine}

The histological examination of jejunum revealed an improvement in villus height, villus height/crypt depth ratio, and less mononuclear cellular infiltration in all the groups fed either dandelion leaves or fenugreek seeds alone or in combination with or without enzyme treatment when compared with the control group. Best results were obtained in the treatment group where the combination of enzyme treated dandelion leaves and fenugreek seeds were used. Increased villus height helps to enhance the absorptive surface area for better 


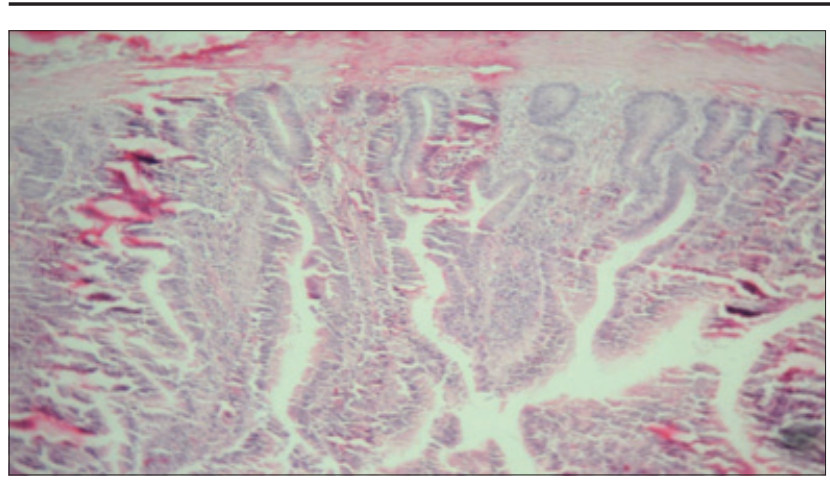

Figure-15: Jejunum from $\mathrm{T}_{6}$ showing thickening of villi and increase in height of villi $(\mathrm{H}$ and $\mathrm{E}, \times 2.5)$.

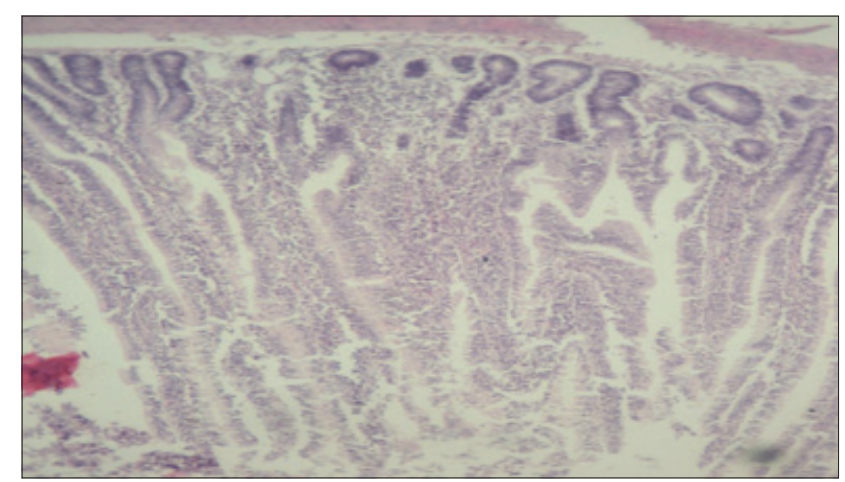

Figure-16: Jejunum from $T_{7}$ showing normal villus architecture with increase in thickness and height of villus, occasional areas of cellular infiltration compared to control group ( $\mathrm{H}$ and $\mathrm{E}, \times 2.5)$.

utilization of nutrients as reported by Adil et al. [26] with the use of feed additives in broiler chicken. Similarly, Abdel-Rahman et al. [27] and Debnath et al. [28] reported that the supplementation of herbal products in the diet of broiler chicken enhance intestinal villus height and surface area, resulting in better intestinal health. The short or damaged villi impair the absorption of the intestine, which might lead to poor performance of birds [29]. In addition, enzyme supplementation has been reported to improve villus height and villus height/crypt depth ratio in poultry $[14,30]$. Moreover, in the present study, the jejunal crypt depth decreased non-significantly in the treatment groups compared to control. The crypts are responsible for production of enterocytes required for renewal of villi and the more the crypt is demanded in terms of cell renewal, the greater its depth [31], thus indicating that the villi were not compromised in any way in all the treatment groups fed dandelion leaves and fenugreek seeds either alone or in combination with or without enzyme addition. Furthermore, there was an improvement in the villus height/crypt depth ratio in all the treatment groups which has been regarded as a good indicator of better intestinal health [31]. The beneficial effect on jejunal histomorphology by dandelion leaves and fenugreek seeds might be attributed to their anti-microbial action which in turn has been reported to decreases the inflammatory reactions at the mucosa, thereby increasing the villus height $[32,33]$. Additional improvement in the intestinal morphology by the addition of enzymes may be because dietary inclusion of the enzymes helps to degrade the nonstarch polysaccharides and diminish their negative impact on the gut morphology as they have been reported to suppress the gut morphological development at higher levels [14].

\section{Conclusion}

The dandelion leaves and fenugreek seeds have hepato-protective nature and beneficial effect on the intestinal morphology, particularly when included along with enzymes in the diet of broiler chicken.

\section{Authors' Contributions}

This study is the part of M.V.Sc. Thesis of the first author SQ, who carried out the research under the guidance of MTB. IS, UA helped during the trial and MSM in the processing of samples. SA provided necessary guidelines during the work and helped in the technical writing of the article. YAB helped in thorough revision of the manuscript. All authors have read and approved the final version of the manuscript.

\section{Acknowledgments}

The authors are thankful to the Directorate of Research, Sher-e-Kashmir University of Agricultural Sciences and Technology of Kashmir for providing necessary funding for the work.

\section{Competing Interests}

The authors declare that they have no competing interests.

\section{References}

1. Windisch, W., Schedle, K., Plitzner, C. and Kroismayr, A. (2008) Use of phytogenic products as feed additives for swine and poultry. J. Anim. Sci., 86: 140-148.

2. Hashemi, S.R. and Davoodi, H. (2010) Phytogenics as new class of feed additive in poultry industry. J. Anim. Vet. Adv., 9(17): 2295-2304.

3. Brugalli, I. (2003) Alternative power: The use of herbal and nutraceutical as modulators of immunity and animal performance. In: Symposium on Management and Nutrition Poultry and Pigs, Campinas. Proceedings: Brazilian Animal Nutrition College. p167-182.

4. Husain, M. (2001) Geography of Jammu and Kashmir. Rajesh Publication, New Delhi, India. p28.

5. Malik, H.A., Khuroo, A.A. and Dar, G.H. (2011) Ethnomedicinal uses of some plants in the Kashmir Himalayas. Indian J. Tradit. Knowl., 10(2): 362-366.

6. Mir, M.A., Sawhney, S.S. and Jassal, M.M.S. (2013) Qualitative and quantitative analysis of phytochemicals of Taraxacum officinale. Wudpeck. J. Pharm. Pharmocol., 2(1): $1-5$.

7. Bash, E., Ulbricht, C., Kuo, G. and Smith, M. (2003) Therapeutic applications of fenugreek. Altern. Med. Rev., 8: 20-27.

8. Michael, D. and Kumawat, D. (2003) Legend and Archeology of Fenugreek, Constitutions and Modern Applications of Fenugreek Seeds. International Symposium, USA. p41-42.

9. Galib, A.M., Al-Kassi, A. and Noor, M.W. (2010) A 
Comparative study on diet supplementation with a mixture of herbal plants and dandelion as a source of prebiotics on the performance of broilers. Pak. J. Nutr., 9(1): 67-71.

10. Rabia, J.A. (2010) Effect of using fenugreek, parsley and sweet basil seeds as feed additives on the performance of broiler chickens. Int. J. Poult. Sci., 9(3): 278-282.

11. Raziq, F., Khan, S., Naila, C. and Asad, S. (2012) Effect of water based infusion of Lycium, Aloe barbedensis, Pimpinella anisum, Berberis Trigonella foenum-graecum and Allium sativum on the performance of broiler chicks. Pak. Vet. J., 32(4): 593-596.

12. Yousuf, S., Banday, M.T., Adil, S., Salahuddin, M. and Rehman, M. (2012) Efficacy of enzyme and yeast supplements on performance of broiler chicken fed high fiber diets. Indian J. Anim. Sci., 82(4): 410-414.

13. Tufarelli, V., Dario, M. and Laudadio, V. (2007) Effect of xylanase supplementation and particle-size on performance of guinea fowl broilers fed wheat-based diets. Int. J. Poult. Sci., 6: 302-307.

14. Ayoola, A.A., Malheiros, R.D., Grimes, J.L. and Ferket, P.R. (2015) Effect of dietary exogenous enzyme supplementation on enteric mucosal morphological development and adherent mucin thickness in Turkeys. Front. Vet. Sci., 2(45): 1-8.

15. BIS (1992). Poultry Feeds Specification. $4^{\text {th }}$ Revision. Bureau of Indian Standards. New Delhi, pp. 4.

16. Park, C., Yusi, Z. and Youngsun, S. (2007) Hepatoprotective effect of Dandelion (Taraxacum officinale) against acute liver injury induced by carbon tetrachloride in SpragueDawley rats. Fed. Am. Soc. Exp. Biol., 21(1): 862.

17. Tabassum, N., Shah, M.Y. and Qazi, M.A. (2010) Prophylactic activity of extract of Taraxacum officinale against hepatocellular injury induced in mice. Pharmacol. Online., 2: 344-352.

18. Al-Malki, A., Kamel, A.A., Gamal, A. and Hassan, A. (2013) Hepatoprotective effect of dandelion (Taraxacum officinale) against induced chronic liver cirrhosis. J. Med. Plants Res., 7(20): 26-35.

19. Gulfraz, M., Dawood, A. and Sheeraz, A. (2014) Effect of leaf extracts of Taraxacum officinale on $\mathrm{CCl}_{4}$ induced hepatotoxicity in rats, in vivo study. Pak. J. Pharm., 27(4): 825-829.

20. Onera, A., Cihat, U., Mercan, H., Onturkb, H. and Cengizc, R. (2008) Anti-inflammatory and hepatoprotective activities of Trigonella foenum-graecum. Pharmacol. Online., 2(1): 126-132.

21. Eman, A. (2011) Pathological and biochemical studies on the effect of Trigonella foenum-graecum and Lupinus termis in alloxan induced diabetic rats. World Appl. Sci. J., 12(10): 1839-1850.

22. Schmidt, M. (1979) The delightful Dandelion. J. Organ.
Gard., 26: 112-117.

23. Jackson, B.S. (1982) The lowly dandelion deserves more respect. Can. Geogr. Mag., 102: 54-59.

24. Jassim, M.N., Safanah, A.F. and Omar, M.N. (2012) Identification of dandelion Taraxacum officinale leaves components and study its extracts effect on different microorganisms. J. Al-Nahrain Univ., 15(3): 7-14.

25. Bukhari, S.A., Bhanger, M.I. and Shahabuddin, M. (2008) Antioxidative activity of extracts from fenugreek seeds (Trigonella foenum-graecum). Pak. J. Anal. Environ. Chem., 9(2): 78-83.

26. Adil, S., Banday, M.T., Bhat, G.A., Mir, M.S. and Rehman, M. (2010) Effect of dietary supplementation of organic acids on performance, intestinal, histomorphology and serum biochemistry of broiler chicken. Vet. Med. Int., 2010: 479485, 1-7.

27. Abdel-Rahman, H.A., Fathallah, S.I. and Helal, A.A. (2014) Effect of turmeric (Curcuma longa), fenugreek (Trigonella foenum-graecum L.) and/or bioflavonoid supplementation to the broiler chicks diet and drinking water on the growth performance and intestinal morphometeric parameters. Glob. Vet., 12(5): 627-635.

28. Debnath, B.C., Choudhary, K.B.D., Ravikanth, K., Thakur, A. and Maini, S. (2014) Comparative efficacy of natural growth promoter with antibiotic growth promoter on growth performance and intestinal morphometry in broiler birds. Int. J. Pharmacol. Sci. Health Care, 4: 155-168.

29. Samanya, M. and Yamauchi, K. (2002) Histological alteration of intestinal villi in chickens fed dried Bacillus subtilis var natto. Comp. Biochem. Physiol., 133(4): 95-104.

30. Luo, D., Yanga, F., Yang, X., Yao, J., Shi, B. and Zhou, Z. (2009) Effects of xylanase on performance, blood parameters, intestinal morphology, microflora and digestive enzyme activities of broilers fed wheat-based diets. AsianAust. J. Anim. Sci., 22(9): 1288-1295.

31. Petrolli, T.G., Albino, L.F.T., Rostagno, H.S., Gomes, P.C., Tavernari, F. and Balbino, E.M. (2012) Herbal extracts in diets for broilers. R. Bras. Zootech., 41(7): 1683-1690.

32. Loddi, M.M., Moraes, V.M.B., Nakaghi, L.S.O., Tucci, F.M., Hannas, M.I. and Ariki, J.A. (2004) Mannan oligosaccharide and organic acids on performance and intestinal morphometric characteristics of broiler chickens. In: Proceedings of the 20th Annual Symposium. p45.

33. Mahmood, S., Rehman, A., Yousaf, M., Akhtar, P., Abbas, G., Hayat, K., Mahmood, A. and Shahzad, M.K. (2015) Comparative efficacy of different herbal plant's leaf extract on haematology, intestinal histomorphology and nutrient digestibility in broilers. Adv. Zool. Bot., 3(2): 11-16. 